\title{
België: een unieke deeltijdeconomie in Europa
}

\author{
Jeroen Horemans *
}

Deeltijdwerk biedt de kans om bij belangrijke levenslooptransities een link met de arbeidsmarkt te behouden. Dit maakt deeltijdbanen in Europa tot een van de drijvende krachten achter de toename in het aantal werkenden tijdens de voorbije decennia. Deeltijdarbeid is echter zeer heterogeen, aangezien een vermindering van de arbeidsprestatie onder verschillende voorwaarden kan gebeuren, wat belangrijke verschillen tussen landen tot gevolg heeft. Dit artikel onderzoekt eerst of deeltijdwerk unieke kenmerken vertoont in België, een onderbelichte casus wat betreft deeltijdwerk. We maken hiervoor gebruik van data van de European Labour Force Survey en vergelijken de Belgische situatie met de situatie in Nederland en andere Europese landen. Ten tweede gaat dit artikel na of het sociaal beleid mede ondersteunend heeft gewerkt bij de recente groei van deeltijdwerk bij specifieke groepen in België. Op basis van administratieve gegevens wordt beargumenteerd dat het specifieke karakter van deeltijdwerk in Belgie samenhangt met de ondersteuning waarin binnen het werkloosheidssysteem voorzien wordt. In Belgie is deeltijdwerk meestal vrijwillig, wordt het vaker gedaan door oudere werknemers en is het verschil in werkuren beperkt in vergelijking met voltijdwerk. We concluderen dat deeltijdwerk in Belgie gemiddeld een relatieve hoge baankwaliteit kent omdat er vanuit een transitionele arbeidsmarkt logica-specifieke ondersteuning bestaat voor deeltijders.

\section{Inleiding}

De systematische toename van deeltijdwerk is een van de meest ingrijpende structurele veranderingen in verschillende Europese arbeidsmarkten. Het verschijnsel van de deeltijdbanen heeft sinds de jaren negentig van de vorige eeuw een centrale plaats in het arbeidsmarktonderzoek. De focus ligt hierbij op de groei, de sekseverschillen en de kwaliteit van de deeltijdbanen (Blossfeld \& Hakim, 1997; O’Reilly \& Fagan, 1998; Tilly, 1996). Hoewel België met 24,3\% deeltijdwerk in 2015 tot de (sub)top behoort van landen waar deze vorm van werken het meest voorkomt, is over de situatie in België relatief weinig bekend in vergelijking met de deeltijdkampioen Nederland of het Duitse fenomeen van mini-jobs. Dit artikel vult een deel van deze leemte in.

Als onderdeel van een meer flexibele arbeidsmarkt is de toename van deeltijdwerk een van de centrale vraagstukken in het Europees gecoördineerde arbeidsmarktbeleid. Deeltijdbanen stimuleren namelijk de participatie van ondervertegenwoordigde groepen op de arbeidsmarkt (Messenger \& Ray, 2015). Uit internationaal onderzoek is bekend dat de toename van deeltijdbanen gepaard gaat met een aantal structurele veranderingen, zoals de vervrouwelijking van het arbeidsaanbod,

* Jeroen Horemans is werkzaam bij het Centrum voor Sociaal Beleid Herman Deleeck, Universiteit Antwerpen, departement sociologie. E-mail: jeroen.horemans@uantwerpen. be. 
de groei van de dienstensector en een flexibele manier van produceren en consumeren (Buddelmeyer et al., 2008). Tevens is bekend dat er zowel voor werknemers als voor werkgevers een aantal voor- en nadelen verbonden zijn aan deeltijdwerk (Eurofound, 2011; Garnero et al., 2014; OECD, 2010; Tilly, 1996). Hoewel vanuit Europa getracht wordt de kwaliteit van deeltijdbanen te beschermen, bijvoorbeeld met de Europese richtlijn rond deeltijdwerk EC/81/97 (O'Connor, 2013), blijft de sociale bescherming van in deeltijd werkenden op sommige vlakken beperkt (OECD, 2010). Er bestaan dus duidelijk maatschappelijke uitdagingen.

De mate waarin deeltijdwerk echt een optie vormt, hangt af van de manier waarop het is ingebed in het breder arbeidsbestel (Yerkes \& Visser, 2006). Dit artikel bestudeert daarom deeltijdwerk in de Belgische arbeidsmarkt in het verlengde van Schmids (2013) recente werk rond bescherming van sociale risico's in een Transitionele Arbeidsmarkt (TAM). Ten eerste stellen we de vraag of België unieke kenmerken vertoont wat betreft deeltijdwerk. Ten tweede onderzoeken we hoe het sociaal beleid mede ondersteunend heeft gewerkt bij de recente groei van deeltijdwerk bij specifieke groepen in België.

In dit artikel worden eerst de specifieke kenmerken van de groei van deeltijdwerk in België geschetst, in vergelijking met Nederland en Europa als geheel. Vervolgens gaan we na in hoeverre deeltijdbanen in België zijn opgenomen in een sociaal beschermingsmodel dat door de Transitionele Arbeidsmarkt naar voren wordt geschoven en of dit de socio-demografische en baankenmerken kan verklaren. Daarom schetst de derde paragraaf van dit artikel kort de theoretische achtergrond van de Transitionele Arbeidsmarkt. Vervolgens bekijken we hoe deeltijdwerk ingebed is in het Belgische systeem van sociale bescherming, meer in het bijzonder in de werkloosheidsverzekering. Ten slotte komen conclusies en discussie aan de orde.

\section{De cijfers over deeltijdwerk in België, Nederland en de EU}

\section{De trend in de tijd}

In dit deel bekijken we de ontwikkeling van deeltijdwerk in België voor verschillende sociaal-demografische groepen en bespreken we enkele typische kenmerken van deeltijdbanen in België. We maken waar mogelijk de vergelijking met de recente trends in Nederland en in Europa. De vergelijking blijft beperkt tot de oude EU-15-landen omdat in de meeste Oost-Europese landen het aandeel deeltijdwerk beperkt blijft en historisch minder gerelateerd is aan een substantiële toename in de arbeidsparticipatie van vrouwen.

In empirisch onderzoek bestaan drie opties om deeltijdwerk vast te stellen. Een eerste manier is simpelweg de respondent te vragen of deze voltijds of deeltijds werkt. Een tweede optie is een om het aantal uren te bevragen en vervolgens een strikt onderscheid te maken tussen meer of minder dan 30 (of 35) uren werken. Een derde optie is een combinatie van de twee voorgaande benaderingen. De hierna te tonen cijfers zijn gebaseerd op de data van de European Labour Force Survey (EU-LFS), die gebruikmaakt van de eerste optie. Daarin zijn parttime werkenden, dus personen die gewoonlijk minder dan het normale aantal arbeidsuren werken. Deze definitie omvat alle vormen van deeltijdwerk, dus ook 
halve dagen werken, werken op een, twee of drie dagen per week, et cetera. De data voor Nederland en Zweden vormen een uitzondering. Voor deze landen wordt in de EU-LFS deeltijdwerk gedefinieerd op basis van 'normaal minder dan 35 uur per week werken' (voor een gedetailleerde discussie van de voor- en nadelen van elke benadering, zie Van Bastelaer et al., 1997).

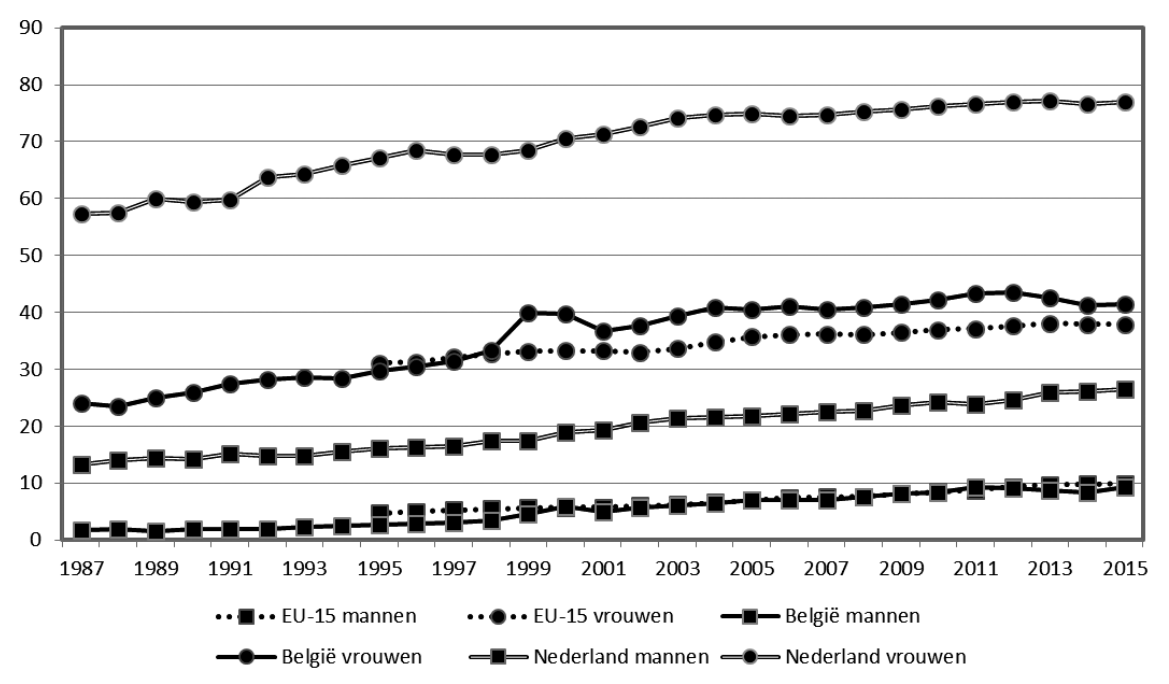

Figuur 1 Trend deeltijdwerk (\% 15-64-jarigen), België, Nederland en Europa, naar geslacht, 1983-2013; Bron: Eurostat: EU-LFS

Figuur 1 geeft de groei van het deeltijdwerk in België, Nederland en de EU weer tijdens de laatste dertig jaar. Globaal volgt België de algemene stijging van het aandeel deeltijdwerkenden in Europa. De toename is substantieel en illustreert de voortschrijdende feminisering van het arbeidsaanbod in een groeiende diensteneconomie, die ook plaatsvond in de meeste andere Europese landen (Buddelmeyer et al., 2008). Bij mannen ligt het aandeel deeltijdwerk in België rond het Europese gemiddelde. Het aandeel deeltijdwerk bij vrouwen in België was lange tijd enkele procentpunt hoger dan het Europese gemiddelde, maar het lijkt de laatste jaren te convergeren naar het Europese gemiddelde. In 2015 werkte bijna 1 op 4 werknemers in België in deeltijd. Dit is van eenzelfde orde van grootte als het aandeel deeltijdwerk in Ierland, Denemarken, Zweden en het Verenigd Koninkrijk, maar blijft nog ver achter de uitzonderlijke situatie in Nederland, waar bijna de helft van alle werkenden een deeltijdbaan heeft (Eurostat, 2015b). Zoals figuur 1 aangeeft, werken zowel mannen als vrouwen in Nederland meer in deeltijd dan in de rest van Europa.

Sociaal-demografische kenmerken bij deeltijdwerk

Wanneer het deeltijdwerk uitgesplitst wordt naar sociaal-demografische kenmerken, komen enkele unieke karakteristieken van de Belgische arbeidsmarkt aan de oppervlakte. Een uitsplitsing naar leeftijd geeft een eerste indicatie van de 
specifieke samenstelling van de deeltijdwerkende populatie in België (figuur 2 en 3). Terwijl België een opvallende stijging van deeltijdwerk bij 50-plussers kende, nam in andere Europese landen deeltijdwerk voornamelijk bij jongeren toe. Deze trend is in het bijzonder in Nederland te zien. Meer recent echter, sinds de start van de crisis in 2008, nam ook deeltijdwerk bij jongeren meer dan gemiddeld toe in België.

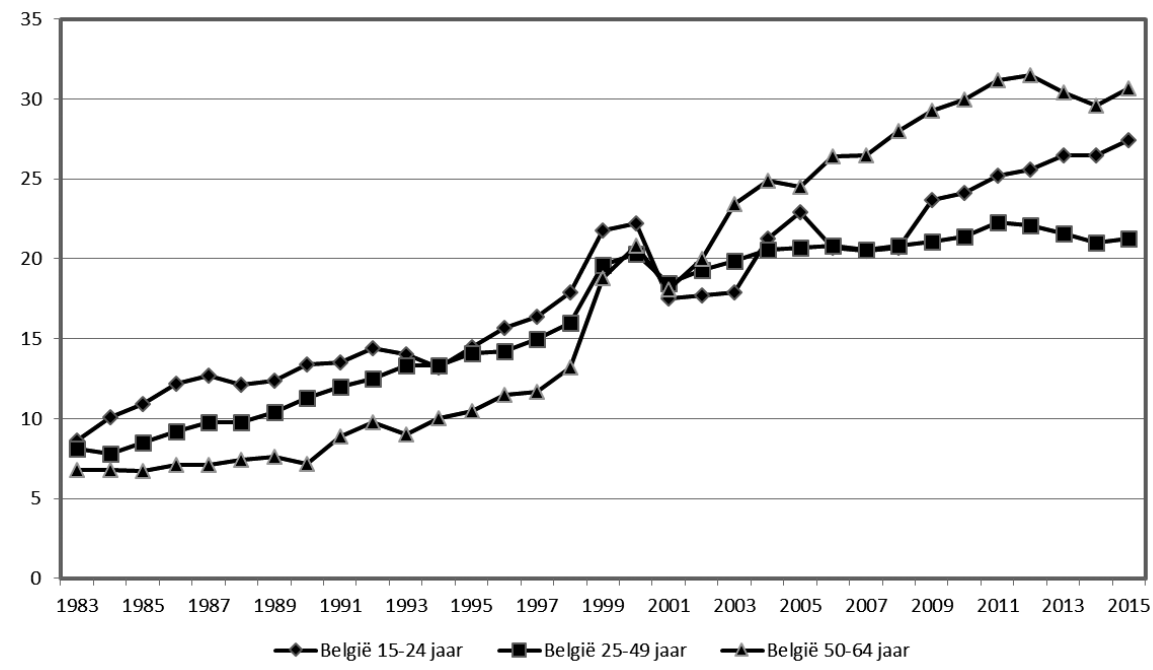

Figuur 2 Trend in het aandeel deeltijdwerk (\% van 15-64-jarigen) naar leeftijd in België, 1983-2015; Bron: Eurostat: EU-LFS

Uit oogpunt van de gezinssituatie is de laatste jaren waar te nemen dat deeltijdwerk zowel in België als in Nederland relatief meer toenam bij kinderloze gezinnen. Het aandeel deeltijdwerk blijft wel, zowel in België, Nederland als in de rest van Europa, groter wanneer er kinderen zijn (Eurostat, 2015b). Dit hangt samen met het veranderend leeftijdsprofiel van de in deeltijd werkenden. Jongeren die nog geen kinderen hebben of ouderen zonder inwonende kinderen, zijn dus mede verantwoordelijk voor de recente toename in deeltijdwerk in België en Nederland. Dit contrasteert met de wijdverspreide veronderstelling dat deeltijdwerk sterk geconcentreerd is bij vrouwen met kinderen. Naast zorg voor kinderen bestaan er dus andere redenen waarom iemand deeltijds werkt, zoals het volgen van een opleiding, ziekte, onvrijwillig deeltijdwerken, pensionering. Deze verschillende redenen zijn vaak gerelateerd aan de kwaliteit van de deeltijdbaan (Horemans, 2012). 


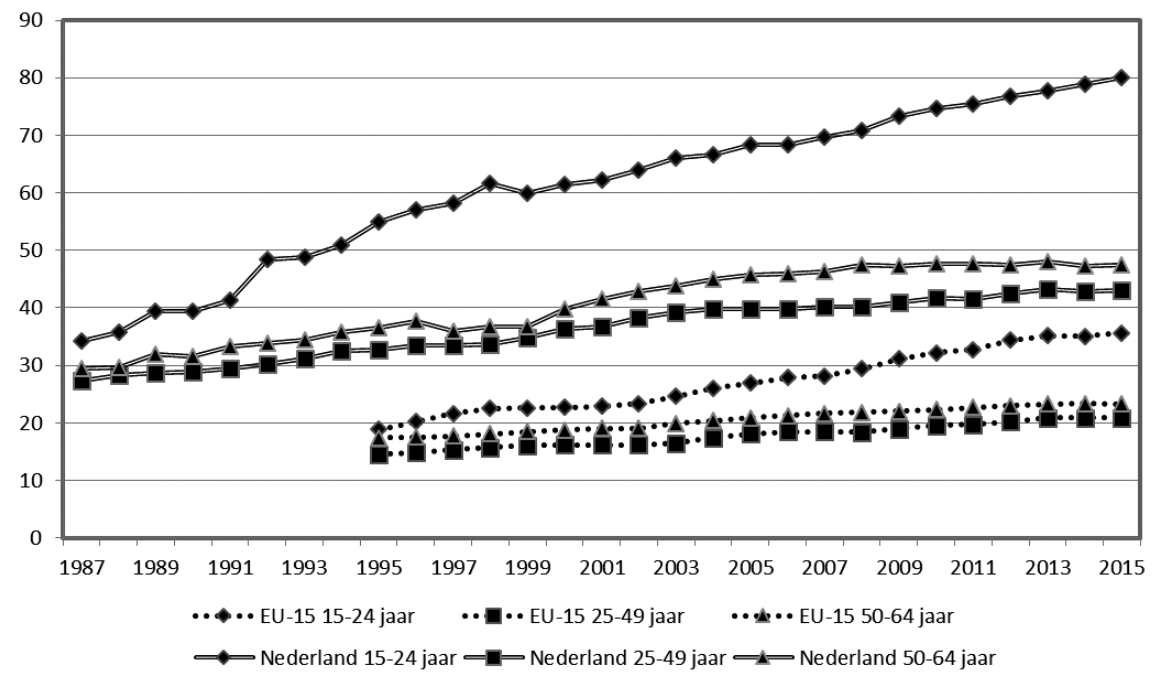

Figuur 3 Trend in het aandeel deeltijdwerk (\% van 15-64-jarigen) naar leeftijd in Nederland en EU-15, 1983-2015; Bron: Eurostat: EU-LFS

De kwaliteit van deeltijdbanen

Deeltijdbanen kunnen sterk in kwaliteit verschillen. In het bijzonder worden kleinere deeltijdbanen (banen van minder dan 15, 20 of 25 uur) en 'onvrijwillige' deeltijdbanen gezien als problematisch in termen van loonhoogte en stabiliteit van tewerkstelling (Messenger \& Ray, 2015). Onvrijwillig in deeltijd werken wordt meestal dusdanig gedefinieerd, wanneer mensen die in deeltijd werken, een voltijdse betrekking zoeken, maar er geen vinden. Dit is een van de redenen die opgegeven worden, wanneer deeltijders bevraagd worden over hun motief om in deeltijd te werken. Andere redenen voor deeltijdwerk kunnen zijn: ziekte of arbeidsongeschiktheid, het volgen van een opleiding, zorg voor kinderen of andere afhankelijke gezinsleden, andere familiale of persoonlijke verantwoordelijkheden en pensionering. Al deze redenen worden meestal gekoppeld aan 'vrijwillige' deeltijdbanen.

Aangezien een vermindering in de arbeidsduur ten opzichte van de 'normale' arbeidsduur verschillende vormen kan aannemen, verschilt deeltijdwerk inhoudelijk tussen landen. Door te kijken naar het gemiddeld aantal uur dat mensen in deeltijd of voltijd werken, ontstaat een indicatie van de grootte van deeltijdwerk in een land. In 2014 werkten deeltijders gemiddeld 24,2 uur per week in België, ten opzichte van gemiddeld 39,2 uur in een voltijdbaan. Dit verschil in werkuren tussen deeltijd en voltijd is de laatste jaren afgenomen door een stijging in het aantal uren dat deeltijders gemiddeld werken (Eurostat, 2015a). In vergelijking met het Europese gemiddelde kent België een relatief korte werkweek voor voltijd werkenden en een relatief lange werkweek voor deeltijders. In het Verenigd Koninkrijk, Ierland, Spanje, Denemarken, Duitsland en Portugal betekent 'deeltijd' gemiddeld effectief minder dan de helft van een voltijdse baan. In België bedraagt een deeltijdbaan gemiddeld $62 \%$ van een voltijdbaan (Eurostat, 2015a). 
Over het algemeen verdienen in deeltijd werkenden minder per uur omdat deeltijdwerk vaker voorkomt in laag betalende sectoren en beroepen (Matteazzi et al., 2012). De schattingen van het loonverschil tussen deeltijds en voltijds werkenden in België verschilt sterk van studie tot studie, afhankelijk van de definities, de data en de schattingsmethode. Sommige studies kijken enkel naar vrouwen of mannen, terwijl andere studies de vergelijking maken tussen mannen en vrouwen. Op basis van een enquête van de Algemene Directie Statistiek van Statistics Belgium (ADS) ${ }^{1}$ verdienden voltijds werkenden in 2012 gemiddeld bijna $16 \%$ - rond de 3 euro bruto per uur - meer dan in deeltijd werkenden (Instituut voor de gelijkheid van vrouwen en mannen \& FOD WASO, 2015). Studies die België internationaal vergelijken, tonen aan dat het loonverschil tussen deeltijds en voltijds werkenden relatief beperkt blijft, zowel bij mannen als bij vrouwen (Manning \& Petrongolo, 2005; Matteazzi, Pailhé \& Solaz, 2013; O’Dorchai et al., 2007). Ook blijkt het armoederisico dat samenhangt met een deeltijdbaan, in een Europees vergelijkend perspectief relatief beperkt in België (Horemans \& Marx, 2013).

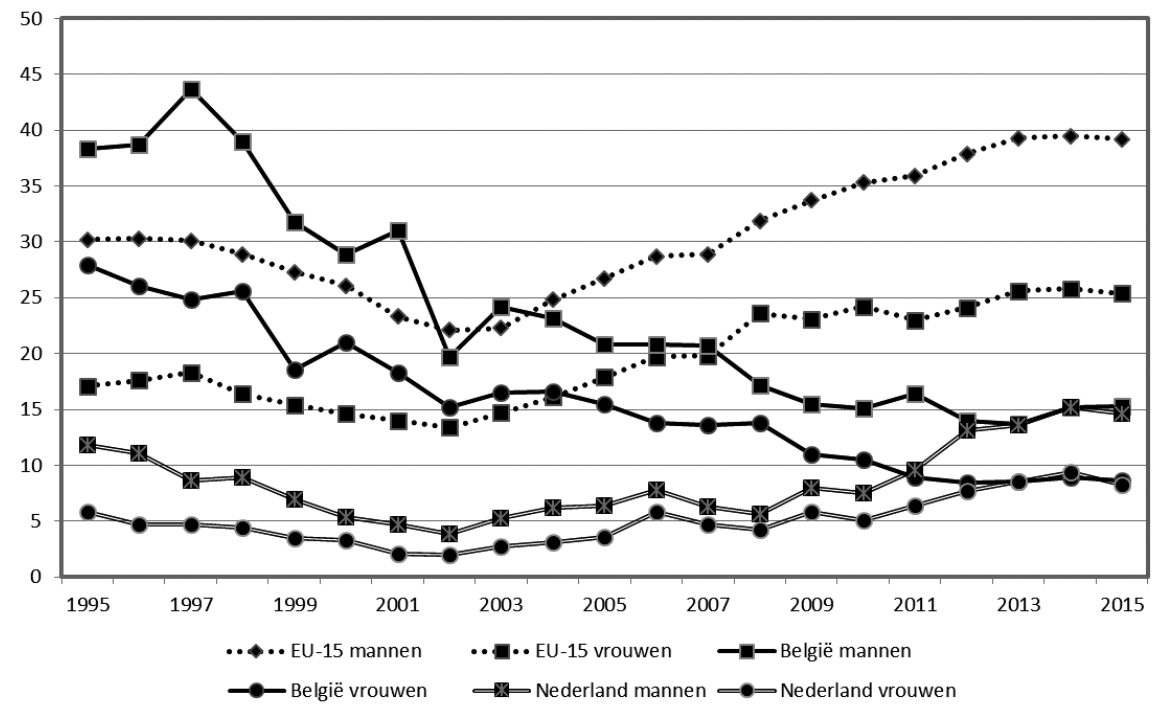

Figuur 4 Trend onvrijwillig deeltijd (\% van deeltijdwerk) België, Nederland en EU-15, 1983-2013; Bron: Eurostat: EU-LFS

Opvallende genderverschillen zijn aanwezig bij de redenen waarom iemand in deeltijd werkt. Zoals in andere Europese landen werken vrouwen in België voornamelijk in deeltijd om werk en gezin te combineren. Mannen werken meer onvrijwillig in deeltijd, maar ook om andere redenen, zoals het volgen van een opleiding of deeltijdpensionering, maar niet om hun werk en gezinsleven op elkaar af te stemmen (Fouarge \& Muffels, 2008). De trend in onvrijwillig deeltijdwerk (figuur 4) laat zien dat dit aandeel tijdens de recente crisis in de meeste Europese landen toenam, ook in Nederland. Opvallend is echter de omgekeerde 
beweging die we voor België waarnemen, waar het onvrijwillig deeltijdwerk een sterk dalende trend vertoont, voor zowel mannen als vrouwen.

\section{Deeltijdwerk in België: balans tussen sociale bescherming, activering en de 'pluri-actieve welvaartsstaat'}

Het eerste deel van dit artikel toonde enkele typische kenmerken van deeltijdwerk in België, in het bijzonder het vrijwillige karakter, het aanzienlijke gebruik door oudere werknemers, het feit dat deeltijdwerk een substantieel aantal uren omvat en dat deeltijders een beperkte loonkloof kennen ten opzichte van voltijds werkenden. Om het unieke karakter van het Belgische deeltijdwerk te begrijpen, worden in dit deel een aantal institutionele kenmerken beschouwd die bijdragen tot een beter begrip van deeltijdwerk in België. In het bijzonder gaat het daarbij om de institutionele veranderingen, ontstaan vanuit het denken rond de Transitionele Arbeidsmarkt (TAM).

\section{Deeltijdwerk vanuit het Transitionele Arbeidsmarkt-perspectief}

In wat volgt, zal de Transitionele Arbeidsmarkt-benadering gebruikt worden om de langetermijntrends in de Belgische arbeidsmarkt te duiden, en in het bijzonder de toename en het specifieke karakter van deeltijdwerk. De TAM-benadering probeert een antwoord te formuleren op hoe we dienen om te gaan met de risico's die zijn verbonden aan bepaalde transities, en toch een betaalbare verzorgingsstaat te blijven behouden (Schmid, 1998, 2008). Volgens Muffels (2006) is de Transitionele Arbeidsmarkt in de eerste plaats een metafoor om de realiteit van de hedendaagse arbeidsmarkt te verbeelden. De benadering beschrijft en analyseert de transities die individuen tijdens hun levensloop maken in de arbeidsmarkt zelf en tussen de arbeidsmarkt en andere domeinen zoals opleiding, zorg, werkloosheid/inactiviteit of pensionering. De TAM-benadering veronderstelt dat de arbeidsmarkt beter functioneert wanneer de transities die individuen maken, worden ondersteund om een continue inzetbaarheid over de levensloop mogelijk te maken.

In tegenstelling tot het dominante beleidsdebat over 'making work pay' staat 'making transitions pay' centraal bij het denken vanuit de Transitionele Arbeidsmarkt. Belangrijk daarbij is dat naast transities tussen verschillende levensfasen ook transities binnen een stabiele baan, in combinatie met andere levensdomeinen, dienen te worden gefaciliteerd. Tijdelijk vrijwillig in deeltijd werken maakt een integraal deel uit van een Transitionele Arbeidsmarkt. De onderliggende sociale verzekeringslogica bestaat immers uit een risicospreiding van werk en andere levensdomeinen over de levensloop (Schmid, 2008).

In wat volgt, bekijken we op welke manier deeltijdbanen ingebed zijn in het Belgisch systeem van sociale bescherming. Meer specifiek wordt belicht of en hoe elementen van de logica van de Transitionele Arbeidsmarkt in het systeem aanwezig zijn. Er wordt, met andere woorden, geanalyseerd of transities naar deeltijdwerk 'het waard zijn' vanuit socialezekerheidsperspectief. 
De Transitionele Arbeidsmarkt als verklaring voor het unieke karakter van deeltijdwerk in Belgie

Met de aanpassing van de welvaartsstaat aan nieuwe contextuele uitdagingen, zoals de toename van het percentage werkende vrouwen, veranderde in België de relatie tussen werk en uitkeringen gestaag. Deze trend is zichtbaar in de verschillende uitkeringstypes van de Rijksdienst voor Arbeidsvoorzieningen (RVA). De RVA kent het recht op verschillende types werkloosheidsuitkeringen toe. In België bestaan er voor de verschillende domeinen van de sociale zekerheid andere instellingen. De RVA is vergelijkbaar met het Uitvoeringsinstituut Werknemers verzekeringen (UVW) in Nederland, maar kent een beperktere invulling.

In de Belgische context bestaan drie te onderscheiden groepen van rechthebbenden op een bepaald type (werkloosheids) uitkering door de RVA. Elk van de drie types heeft een eigen regelgeving en een specifieke onderliggende reden waarom iemand het recht heeft op een bepaalde uitkering. Een eerste groep zijn de gewone vergoede werklozen, mensen die hun baan verliezen en daarom een vervangingsinkomen ontvangen. Ten tweede zijn er werknemers die met een uitkering ondersteund worden om te werken, vaak in activeringsmaatregelen. De derde groep werknemers heeft de mogelijkheid om met steun van de RVA hun arbeidstijd aan te passen. Het is in het bijzonder deze laatste groep die nauw aansluiting vindt bij het idee van de Transitionele Arbeidsmarkt.

Figuur 5 illustreert het toenemend belang van ondersteunende maatregelen van de RVA in aanvulling op de klassieke werkloosheidsverzekering. Sinds 2009 zijn er zelfs bijna evenveel vergoede werklozen (groep 1) als personen die door de RVA ondersteund worden (groep 2) of met een compensatie van de RVA in staat gesteld worden om hun arbeidstijd aan te passen (groep 3).

De eerste groep van rechthebbenden op een RVA-uitkering - de vergoede werklozen - volgt het oorspronkelijke idee van verzekering en solidariteit binnen de welvaartsstaat. Deze groep volgt een cyclisch patroon dat sterk samenhangt met de economische conjunctuur (figuur 5). Oorspronkelijk was dit systeem van uitkeringen gebaseerd op een verzekeringsprincipe waarbij het niveau van de bijdragen en de uitkering aan elkaar gekoppeld zijn. Bijdragen aan de werkloosheidsverzekering zijn wel nog proportioneel gerelateerd aan de lonen, maar de uitkeringen zijn tegenwoordig minder gebaseerd op bijdragen uit het verleden (Hemerijck \& Marx, 2009).

Deeltijdwerk is mee geïntegreerd in het systeem van werkloosheidsverzekering, mede onder druk van internationale organisaties en richtlijnen ( ILO, 1988, 1994). Iemand die in België in deeltijd werkt, kan ook volledige rechten opbouwen in de werkloosheidsverzekering, maar dit is moeilijker omdat de periode om daarvoor in aanmerking te kunnen komen, gebaseerd is op voltijds werken (OECD, 2010). Met andere woorden, deeltijders moeten een langere periode doorlopen om dezelfde rechten op te bouwen omdat ze minder uren per week werken. Anderzijds, wat betreft de hoogte van de uitkering, blijkt in de praktijk slechts een beperkt aandeel deeltijders een proportioneel lagere werkloosheidsuitkering te ontvangen na een deeltijdbetrekking. Dit komt doordat deeltijdwerkenden in België vaak een substantieel aantal uren werken en zo toch voldoende rechten kunnen opbouwen om gelijkgesteld te worden met voltijds werknemers. 


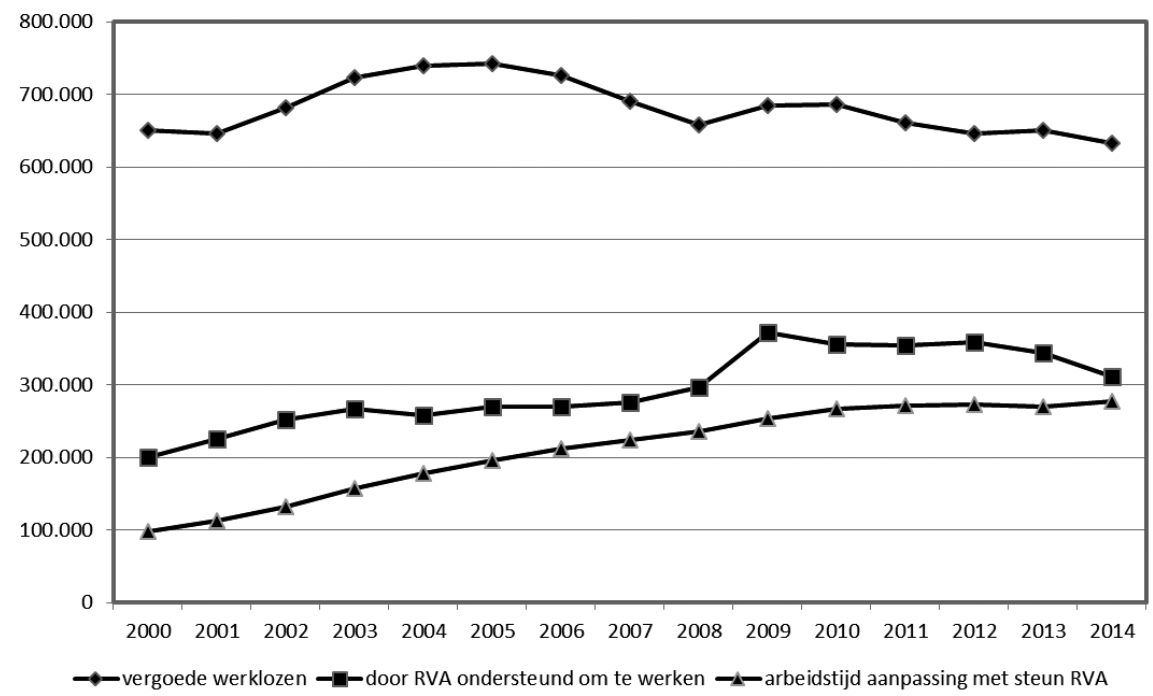

Figuur 5 Trends van het aantal rechthebbenden op een werkloosheidsuitkering in de periode 2000-2014, per groep rechthebbende, jaargemiddelden; Bron: RVA, 2015

Sinds de crisis van de jaren tachtig heeft de sociale bescherming in België een meer preventief en aanmanend karakter gekregen. Dit komt tot uiting in het idee van de actieve welvaartsstaat (Vandenbroucke, 2000, 2013). Naast de passieve inkomensbescherming tegen bijvoorbeeld het risico van werkloosheid groeide het belang van activerende maatregelen om mensen met een uitkering terug naar werk te begeleiden of aan het werk te houden. Er bestaat echter een spanningsveld tussen de activeringslogica en het oorspronkelijke doel van inkomensbescherming. Zo wijst Vandenbroucke (2013) op het dilemma tussen de behoefte aan voldoende sociale bescherming en mogelijke inactiviteitsvallen voor deeltijdwerk (situaties waarin personen weinig financiële meeropbrengst kennen bij de overgang van inactiviteit naar deeltijdwerk).

De tweede groep van rechthebbenden op een werkloosheidsuitkering volgt de logica van de actieve welvaartsstaat. Deze groep werknemers wordt ondersteund door activeringsmaatregelen gericht op specifieke doelgroepen, zoals langdurig werklozen (RVA, 2014). De grootste groep van ondersteunde werknemers zijn echter de tijdelijk werklozen en personen met een inkomensgarantie-uitkering (IGU). Het systeem van tijdelijke werkloosheid is vergelijkbaar met het Duitse systeem van 'Kurzsarbeit'; het gebruik ervan piekte duidelijk aan het begin van de crisis. Een inkomensgarantie geeft iemand die in deeltijd begint te werken na een periode van werkloosheid, een verhoogde tegemoetkoming om te vermijden dat iemand die het werk hervat minder inkomen heeft dan wanneer hij/zij in de werkloosheid blijft. Dit is dus in essentie een vergoeding voor onvrijwillig in deeltijd werkenden. Een vereenvoudiging in de toekenning van een uitkering 
tijdens de crisis van de jaren tachtig deed het aantal onvrijwillig in deeltijd werkenden exploderen, maar door een beperkende maatregel in 1992 daalde het aantal opnieuw (OECD, 2003). Sinds 2000 zien we slechts een zeer beperkte toename in de toekenning van een inkomensgarantie-uitkering, mogelijk omdat inactiviteitsvallen blijven bestaan (Bogaerts, 2008; Bogaerts et al., 2010).

Naast het idee van de actieve welvaartsstaat heerste in het begin van de jaren 2000 in België ook een debat rond de 'pluri-actieve' welvaartsstaat (Cantillon, 2000; Vanderweyden, 1999). Dit debat was gerelateerd aan de discussies rond de Transitionele Arbeidsmarkt (Vanderweyden, 2002). Binnen het idee van de 'pluri-actieve' welvaartsstaat vormt werk niet het centrale doel, maar staat de kwaliteit van het leven centraal en krijgen andere levenssferen zoals zorg, studie en vrije tijd ook een meerwaarde (Vanderweyden, 1999). Dit heeft gevolgen voor de manier waarop de welvaartsstaat wordt ingericht.

Binnen dit denkkader kunnen we de derde groep rechthebbenden plaatsen, zij die met steun van een werkloosheidsuitkering hun arbeidstijd kunnen aanpassen. Dat deze groep rechthebbenden een plaats heeft binnen de werkloosheidsverzekering is historisch gegroeid. In het begin werden deze uitkeringen namelijk gezien als een middel om werkloosheid te bestrijden en het economisch draagvlak te versterken (De Lathouwer et al., 2006). Oorspronkelijk bestond een vervangingsplicht van de onderbrekende werknemer door de werkgever. Met de omvorming van loopbaanonderbreking tot tijdskrediet in 2002 - enkel voor de privésector - werd de vervangingsplicht afgeschaft en was het argument van een meer ontspannen loopbaan en kwaliteitsvolle arbeid volgens Vanderweyden (2002) de belangrijkste verantwoording van het nieuwe systeem.

Mensen met een loopbaanonderbreking en met tijdskrediet, respectievelijk binnen de overheids- en privésector, zijn de grootste groepen rechthebbenden die met een gefixeerde uitkering ondersteund worden om vrijwillig hun arbeidstijd aan te passen. In België kan een werknemer 'tijdskrediet' opnemen om zijn/haar beroepsloopbaan te onderbreken of om zijn/haar arbeidsprestaties tijdelijk te verminderen. Deze werknemer heeft dan recht op een uitkering, tenminste als men tijdskrediet opneemt met motief. Doel van het stelsel is een betere combinatie van werk en gezin. Tot 2015 bestond zowel voor een tijdskrediet-metmotief als voor een tijdskrediet-zonder-motief de mogelijkheid om een uitkering te ontvangen. Sinds 2015 geeft enkel tijdskrediet-met-motief ${ }^{2}$ nog een recht op een uitkering. Het begrip 'met motief' mag niet verward worden met thematische verloven, een ander subtype van de groep van rechthebbenden die hun arbeidstijd in bepaalde situaties kunnen verminderen (ouderschapsverlof, verzorging van een ziek familielid of palliatieve zorgen). Thematische verloven kunnen onder bepaalde voorwaarden worden opgenomen voor of na loopbaandonderbreking/ tijdskrediet. Bij onderbrekingen aan het einde van de loopbaan ofwel 'landingsbanen' bestaat er een verhoogde uitkering die kan blijven bestaan tot pensionering. ${ }^{3}$

Volgens De Lathouwer et al. (2006) zijn er vier types personen in het systeem van loopbaanonderbreking/tijdskrediet: (1) vrouwen met jonge kinderen, (2) personen die zelf een zelfstandige activiteit beginnen, (3) personen die een 
partner ondersteunen in hun zelfstandige activiteit, en (4) ouderen in een 'landingsbaan'. Voornamelijk de dominantie van deze laatste groep, bijna $70 \%$ van alle loopbaan/tijdskrediet met een verminderde prestatie (RVA, 2014), voedde het recente maatschappelijke debat rond de effectiviteit van het tijdskrediet voor het verhogen van de problematisch lage arbeidsmarktparticipatie van ouderen in België (Vansteenkiste et al., 2015). Hoewel dit vaak als reden wordt aangehaald, blijken werknemers in landingsbanen niet noodzakelijk langer te werken. In 2015 werd, samen met andere beperkende maatregelen in de regelgeving, de minimumleeftijd voor tijdskrediet in het kader van eindeloopbaan verhoogd van 55 tot 60 jaar.

Figuur 5 laat een algehele stijging zien in het aantal personen dat gebruikmaakt van een werkloosheidsuitkering bij een vermindering van de arbeidsprestatie. Deeltijdwerk is dus geïntegreerd in de werkloosheidsverzekering, maar is ook typerend voor de uitbouw van een moderne welvaartsstaat die rekening houdt met de noodzaak van een breed economisch draagvlak alsmede van een individuele levensloop. Deeltijdwerken wordt ondersteund binnen een activeringsbeleid voor degenen die het werk in deeltijd hervatten met een inkomensgarantie-uitkering, hoewel de financiële compensatie in veel gevallen beperkt blijft (Bogaerts et al., 2010). Anderzijds geven uitkeringen werknemers de mogelijkheid om de werk-privébalans te optimaliseren, waarbij het inkomensverlies voor het gezin beperkt blijft doordat de vermindering van de arbeidsprestatie beperkt blijft en er in een compensatie wordt voorzien (Devisscher \& Van Pelt, 2005; RVA, 2007). Het grote aandeel ouderen en de anciënniteitkoppeling van de lonen in België maken ook dat werknemers met een relatief hoog loon tijdskrediet opnemen (De Lathouwer et al., 2006).

Geconcludeerd kan worden dat transities in België ondersteund worden bij een stabiele link met de arbeidsmarkt in deeltijdbanen. De ondersteuning van in deeltijd werkenden in verschillende systemen en de sterke inbedding in het klassieke werkloosheidssysteem maken dat deeltijdwerk in België vaak vrijwillig is en dat gemiddeld genomen het loonverschil met voltijdwerk beperkt blijft. Door de verschillende systemen wordt deeltijds werken namelijk ook mogelijk gemaakt voor werknemers in beter betaalde beroepen, zonder dat deze van baan behoeven te veranderen om deeltijds te werken. De verschillende systemen verklaren ook waarom in België doorgaans een substantieel aantal uren wordt gewerkt in deeltijdbanen. De meerderheid van de werknemers die hun arbeidsprestatie verminderen, doen dit slechts met een vijfde deel en werken dus vaak in vier vijfde banen. Tot slot verklaart het systeem ook de toename in vrijwillig deeltijdwerk bij ouderen omdat tijdskrediet in 'landingsbanen' extra gecompenseerd wordt.

\section{Conclusie en discussie}

Om de trend van deeltijdwerk te begrijpen in het hedendaagse arbeidsbestel bestaan er twee dominante perspectieven. De ene school beschouwt deeltijdwerk als de ideale manier om arbeidstijdvoorkeuren te verenigen tussen de vraag- en 
aanbodkant van de arbeidsmarkt. De andere beziet de verspreiding van deeltijdwerk als een manifestatie van een ongelukkige trend naar segmentatie, ofwel naar het ontstaan van inferieure banen met lage lonen, weinig promotiemogelijkheden en slechte sociale zekerheid (Schmid, 2008, pp. 103-104). Deeltijdwerk wordt dus gekenmerkt door grote diversiteit aan kwaliteit (Messenger \& Ray, 2015; Tilly, 1996). Als belangrijkste vorm van niet-standaard werk en de daarmee gepaard gaande transities en segmentatieprocessen neemt deeltijdwerk een centrale plaats in bij het denken over de hedendaagse arbeidsmarkt.

Globaal genomen volgt deeltijdwerk in België de bredere Europese trend, maar er zijn ook enkele specifieke elementen die samenhangen met de specifieke institutionele context. Met bijna een kwart van de werkenden in een deeltijdbaan kent België een relatief hoog aandeel dat in deeltijd werkt. Zoals in andere landen werken ook in België voornamelijk vrouwen in deeltijd. De toename in deeltijdwerk is de laatste tien jaar sterk geconcentreerd bij ouderen, en meer recent ook bij jongeren. Dit hangt ook samen met de toename in deeltijdwerk bij kinderloze gezinnen, of gezinnen waar kinderen het gezin al hebben verlaten. Hierin verschilt de Belgische situatie duidelijk met de situatie in Nederland. In Nederland is het werken in deeltijd sterk gestegen bij jongeren, scholieren en studenten die een bijbaan hebben.

Twee verklaringen kunnen worden aangedragen voor het opvallende aandeel - en de toename daarin - van deeltijdwerk bij 50-plussers in België. Een eerste verklaring is een cohorte effect waarbij vrouwen die in deeltijd werken, bij de geboorte van kinderen niet meer terugkeren naar een voltijdse betrekking, ook al zijn de kinderen het huis uit. Van dergelijke 'normering' naar deeltijdwerk voor vrouwen, onafhankelijk van de zorgverantwoordelijkheden zoals in Nederland (Yerkes, 2009), blijkt dus vooralsnog geen sprake. De stijging van deeltijdwerk bij ouderen is in België namelijk niet beperkt tot vrouwen. Als tweede verklaring werd beargumenteerd dat andere elementen, specifiek aan het Belgische institutioneel kader, een essentiële rol spelen bij de toename van deeltijdwerk bij ouderen. In het bijzonder de verhoogde uitkering bij een vermindering van prestaties via het systeem van tijdskrediet tot aan de pensionering blijkt populair bij 50 plussers.

Hoewel deeltijdbanen in België ook zeer heterogeen kunnen zijn, blijkt het positieve perspectief van een ideale afstemming tussen vraag en aanbod dominant. In vergelijking met andere Europese landen omvatten deeltijdbanen in België doorgaans een substantieel aantal uren; de loonkloof met voltijdwerkenden blijft relatief beperkt; en slechts een beperkt aandeel van de deeltijdbanen worden onvrijwillig ingevuld. Ook in Nederland worden deeltijdbanen overwegend vrijwillig ingevuld en is het loonverschil relatief klein. Over het vrijwillige karakter bestaat echter veel discussie. De vraag is of het echt een 'vrije keuze' is of een keuze die bepaald is door de context (OECD, 2010). In Nederland blijken verschillende studies aan te geven dat het is wat vrouwen willen (Booth \& Van Ours, 2013). Ook in de België is het nodig om naast de genderspecifieke motieven om in deeltijd te werken, de contextfactoren in rekening te brengen. De motivatie voor deeltijdwerken en de mogelijkheden om dit te doen verklaren volgens Garnero et al. (2014) waarom in het bijzonder vrouwen, die gemiddeld vaker 
deeltijdwerken om zorgredenen, een lager loon ontvangen wanneer ze in kleinere deeltijdbanen (< 25 uur/week) werken. Om gezin en arbeid te kunnen combineren geven vrouwen enerzijds het signaal van minder betrokkenheid met werk en wordt de verdere carrière beperkt. Anderzijds is het soms noodzakelijk voor vrouwen om te veranderen naar een lager betaalde baan om daadwerkelijk in deeltijd te kunnen werken en om arbeid en gezin te kunnen combineren.

Geconcludeerd kan worden dat deeltijdwerken in België sterk aansluit bij het sociaal model van een transitionele arbeidsmarkt. Volgens Schmid (2013) zijn de volgende aspecten van cruciaal belang om de toegevoegde waarde van deeltijdwerk te beoordelen. Ten eerste mag de productiviteit niet worden beïnvloed. Grote deeltijdbanen (> 25 uur) komen vaak in België voor en blijken voor werkgevers het meest winstgevend te zijn omdat de positieve aspecten (flexibele inzet van arbeid en langere openingstijden) in dergelijke situaties zwaarder wegen dan de negatieve aspecten (coördinatieproblemen, verminderde opbouw van ervaring) (Garnero et al., 2014). Ten tweede mag volgens Schmid deeltijdwerk geen onvrijwillige keuze zijn en moet de mogelijkheid dus bestaan om effectief te switchen tussen deeltijd- en voltijdwerk. Ten derde moeten deeltijders op een gelijke manier worden behandeld in termen van loon en sociale bescherming (Schmid, 2013). De populaire systemen van tijdskrediet, loopbaanonderbreking en thematische verloven, in aanvulling op de klassieke werkloosheidsverzekering, maken dat aan deze voorwaarden wordt voldaan. Deze systemen faciliteren de combinatie van (deeltijd)werk en andere levensdomeinen door aanvullende uitkeringen. Dit maakt dat er ook daadwerkelijk transities tussen voltijd- en deeltijdwerken kunnen plaatsvinden. Voor werknemers ziet de situatie er globaal genomen dus rooskleurig uit, althans voor degenen die voldoen aan de voorwaarden om in aanmerking te komen voor de ondersteunende uitkeringen.

Niettegenstaande de populariteit van verschillende systemen die deeltijdwerken ondersteunen, is het voor werkgevers niet altijd eenvoudig om tijdelijk de verminderde prestatie van werknemers op te vangen. Bij beleidsmakers bestaat er ook discussie rond de houdbaarheid van dergelijke systemen in tijden van besparingen. De regeringen-Di Rupo I en -Michel I maakten recent de toegang tot het recht op tijdskrediet strenger en beperkten de voorwaarden waaronder tijdskrediet gepaard kan gaan met een uitkering. Dit gebeurde respectievelijk in 2012 en 2015. Dit maakt dat nu nog veel mensen snel gebruikmaken van de regeling - voor het te laat is om gebruik te maken van de gunstige voorwaarden - maar de vraag is wat de gevolgen zullen zijn voor de populariteit en de kwaliteit van deeltijdwerk in de komende vijf tot tien jaar in België.

\section{Noten}

1 De Enquête naar de Structuur en de Verdeling van de Lonen bevraagt enkel de ondernemingen met minstens tien werknemers in de sectoren van de industrie (de mijnbouw en de vervaardigende industrie, de productie en distributie van elektriciteit, gas en water en de bouw), de handelssector, de horeca, de transportsector, de financiële sector, de immobiliënsector en andere diensten aan bedrijven. 
2 De volgende motieven komen in aanmerking om tijdskrediet op te nemen: een erkende opleiding volgen; zorgen voor zijn kind dat jonger is dan 8 jaar; zorgen voor een ernstig ziek gezins- of familielid tot de tweede graad; palliatieve zorgen verstrekken; zorgen voor zijn gehandicapte kind dat jonger is dan 21 jaar.

3 De hoogte van de uitkering hangt af van de gezinssituatie, de mate van vermindering van de arbeidsprestatie en de leeftijd van de werknemer. Bijvoorbeeld, in 2012 bedroeg de forfaitaire uitkering voor een alleenstaande in het stelsel van landingsbanen (toen werknemers ouder dan 50 jaar) $€ 174,55$ en $€ 132,86$ voor een alleenstaande jonger dan 50 jaar.

\section{Literatuur}

Bastelaer, A. van, Lemaître, G. \& Marianna, P. (1997). The definition of part-time work for the purpose of international comparisons. OECD Labour Market and Social Policy Occasional Papers, No. 22.

Blossfeld, H.-P. \& Hakim, C. (1997). Between equalization and marginalization: Women working part-time in Europe and the United States of America. Oxford: Oxford University Press.

Bogaerts, K. (2008). Bestaan er nog financiële vallen in de werkloosheid en in de bijstand in België? CSB Bericht december 2008: D/2008/6104/03.

Bogaerts, K., Marx, I., Vandelannoote, D. \& Van Mechelen, N. (2010). Activering bij werkloosheid en recht op maatschappelijke integratie. Antwerpen: UA/Centrum voor Sociaal Beleid Herman Deleeck.

Booth, A. \& Ours, J. van (2013). Part-time jobs: what women want? Journal of Population Economics, 26(1), 263-283. doi:10.1007/s00148-012-0417-9.

Buddelmeyer, H., Mourre, G. \& Ward, M. (2008). Why Europeans work part-time? A cross-country panel analysis. In S. Polachek \& K. Tatsiramos (Eds.), Work, earnings and other aspects of the employment relation (Research in Labor Economics, Volume 28) (pp. 81-139). Bingley, UK: Emerald Group Publishing.

Cantillon, B. (2000). Van actieve naar de pluri-actieve welvaartsstaat. Tijdschrift voor Welzijnswerk, 24(230), 5-19.

Council Directive 97/81/EC of 15 Dec, 1997 concerning the Framework Agreement on part-time work concluded by UNICE, CEEP and the ETUC.

Devisscher, S. \& Pelt, A. Van (2005). Impactanalyse van het systeem van loopbaanonderbreking/tijdskrediet in België. Brussel: IDEA Consult.

Eurofound (2011). Part-time work in Europe: European Company Survey 2009. Retrieved from: http://eurofound.europa.eu/.

Eurostat (2015a). Average number of usual weekly hours of work in main job, by sex, professional status, full-time/part-time and occupation (hours). Retrieved from http:/ /ec.europa.eu/eurostat/web/lfs/data/database.

Eurostat (2015b). Part-time employment as a percentage of total employment. Retrieved from http://ec.europa.eu/eurostat/web/lfs/data/database.

Fouarge, D. \& Muffels, R. (2008). Part-time work and childbirth in Europe: Scarring the career or meeting working-time preferences. In R. Muffels (Ed.), Flexibility and employment security in Europe (pp. 223-254). Cheltenham: Edward Elgar.

Garnero, A., Kampelmann, S. \& Rycx, F. (2014). Part-time work, wages, and productivity: Evidence from Belgian matched panel data. Industrial \& Labor Review, 67(3), 926-954.

Hemerijck, A. \& Marx, I. (2009). Continental welfare at a crossroads: The choice between activation and minimum income protection in Belgium and the Netherlands. In B. Palier (Ed.), A long goodbye to Bismarck? The politics of welfare reform in continental Europe (pp. 129-156). Amsterdam: Amsterdam University Press.

Horemans, J. (2012). Understanding women's reasons for working part-time: A multi-country study. Paper presented at the 10th ESPAnet conference, Edinburgh.

Horemans, J. \& Marx, I. (2013). Should we care about part-time work from a poverty perspective? An analysis of the EU15 countries. In M. Koch \& M. Fritz (Eds.), Non- 
standard employment in Europe: Paradigms, prevalence and policy responses (pp. 169189). Houndmills: Palgrave Macmillan.

ILO (1988). Employment promotion and protection against unemployment (No. 168). Geneva, 21 June 1988.

ILO (1994). Part-time work convention (No. 175). Geneva, 24 June 1994.

Instituut voor de gelijkheid van vrouwen en mannen \& FOD WASO (2015). De loonkloof tussen vrouwen en mannen in België: Rapport 2015. Retrieved from: http://igvmiefh.belgium.be/sites/default/files/downloads/83\%20-\%20Loonkloofrapport\%202015.pdf

Lathouwer, L. De, Debacker, M. \& Bogaerts, K. (2006). Zorg in moderne verzorgingsstaten en sociaal beleid: Het Belgische tijdskrediet. Belgische Tijdschrift voor Sociale Zekerheid, 48(3), 367-398.

Manning, A. \& Petrongolo, B. (2005). The part-time pay penalty. CEP Discussion Paper No 679 .

Matteazzi, E., Pailhé, A. \& Solaz, A. (2012). Part-time wage penalties in Europe: A matter of selection or segregation. ECINEQ WP 2012-250.

Matteazzi, E., Pailhé, A. \& Solaz, A. (2013). Does part-time employment widen the gender wage gap? Evidence from twelve European countries. ECINEQ WP 2013-293.

Messenger, J.C. \& Ray, N. (2015). The 'deconstruction' of part-time work. In J. Berg (Ed.), Labour markets, institutions and inequality: Building just societies in the 21st century (pp. 184-209). Cheltenham: Edward Elgar.

Muffels, R. (2006). Het transitionele arbeidsmarktmodel: theorie, empirie en beleid. In P. Ester, R. Muffels \& J. Schippers (Eds.), De arbeidsmarkt in transitie: Dynamiek en levensloop (pp.9-36). Assen: Van Gorcum.

O'Connor, J.S. (2013). Non-standard employment and European Union employment regulation. In M. Koch \& M. Fritz (Eds.), Non-standard employment in Europe: Paradigms, prevalence and policy responses (pp. 46-63). Houndmills: Palgrave Macmillan.

O'Dorchai, S., Plasman, R. \& Rycx, F. (2007). The part-time wage penalty in European countries: how large is it for men? International Journal of Manpower, 28(7), 571-603.

O’Reilly, J. \& Fagan, C. (1998). Part-time prospects: An international comparison of parttime work in Europe, North America and the Pacific Rim. London/New York: Routledge.

OECD (2003). OECD Employment Outlook 2003: Towards more and better jobs. Paris: OECD.

OECD (2010). Employment Outlook 2010: How good is part-time work? (Chapter 4). Paris: OECD Publishing.

RVA (2007). Welke invloed heeft een vermindering van de prestaties met $1 / 5$ via tijdskrediet en loopbaanonderbreking op het gezinsinkomen? Brussel: RVA.

RVA (2014). De RVA in 2014. Volume 2: indicatoren van de arbeidsmarkt en evolutie van de uitkeringen. Brussel: RVA.

Schmid, G. (1998). Transitional labour markets: A new European employment strategy. WZB Discussion Paper No. FS I 98-206.

Schmid, G. (2008). Full employment in Europe: Managing labour market transitions and risks. Cheltenham: Edward Elgar.

Schmid, G. (2013). Sharing risks of labour market transitions: Towards a system of employment insurance. British Journal of Industrial Relations, 53(1), 70-93..

Tilly, C. (1996). Half a job: bad and good part-time jobs in a changing labor market. Philadelphia: Temple University Press.

Vandenbroucke, F. (2000). Op zoek naar een redelijke utopie: De actieve welvaartsstaat in perspectief. Leuven: Garant.

Vandenbroucke, F. (2013). The active welfare state revisited. Brugge: Die Keure.

Vanderweyden, K. (1999). De pluriactieve maatschappij: Over een samenleving die niet alleen oog heeft voor arbeid. Samenleving en Politiek, 6(8), 26-32.

Vanderweyden, K. (2002). Van loopbaanonderbreking naar tijdskrediet: Een verhaal van een wijzigend maatschappelijk discours. PSW-paper 2002/6 Sociale wetenschappen.

Vansteenkiste, S., Kovalenko, M., Verbruggen, M., Mortelmans, D., Vos, A. De, Forrier, A. \& Dries, N. (2015). Vier jaar loopbaan onderzoek binnen Steunpunt WSE: Wat leerden we over loopbanen in Vlaanderen (en daarbuiten)? Retrieved from: http://www.steunpuntwerk.be/system/files/wse-report_2015_03_0.pdf

Yerkes, M. (2009). Part-time work in the Dutch welfare state: The ideal combination of work and care? Policy and Politics, 37(4), 535-552. 
Yerkes, M. \& Visser, J. (2006). Women's preferences or delineated policies? The development of part-time work in the Netherlands, Germany and the United Kingdom. In J.-Y. Boulin, M. Lallement, J.C. Messenger \& F. Michon (Eds.), Decent working time: New trends, new issues (pp. 235-262). Geneve: ILO. 